\title{
DESCRPTION OF TRIGONOMETRY PROBLEM SOLVING ABILITIES BASEN ON PERSONALITY TYPE AND MATHEMATICS LEARNING ANXIETY LEVELS OF THE STUDENT AT SMAN 6 MAKASSAR
}

\author{
Kasriana $^{1)}$, Rasid Ode ${ }^{2)}$ \\ ${ }^{1,2}$ Prodi Pendidikan Matematika Universitas Darussalam Ambon \\ e-mail: kasriana@unidar.ac.id
}

\begin{abstract}
This study aimed to describe the high school students in solving problems based on personality types and levels of anxiety learn. The subjects were students of class $\mathrm{X}$ SMA 6 Makassar with stratified sampling.The results showed that: (1) in understanding the problem, studentstype of idealist high anxiety levels did not write sufficient conditions and a necessary condition; (2) in planning problem solving, students are able to determine the relevant information to solve problems; (3) in carrying out the plan of solving the problem, the students do the problems in accordance with the troubleshooting steps. (1) in understanding the problem, subject idealist with low anxiety level is able to write what is known and what is being asked; (2) in planning problem solving, students are able to find connections between things that are known and things that were asked; (3) in carrying out the plan of solving the problem, the students use the steps that have been prepared. (1) in understanding the problem, students rational types with high anxiety levels did not write sufficient conditions and a necessary condition; (2) in planning problem solving, students are able to receive the information used to determine the formula. (3) in carrying out the plan of solving the problem, students are able to solve problems that have been designed in accordance strategy. (1) in understanding the problem, students rational types with low anxiety levels did not write sufficient conditions and a necessary condition; (2) in planning problem solving, students are able to associate the information on the matter; (3) in carrying out the plan of solving the problem, students are able to use the steps correctly.
\end{abstract}

Keywords : Solving Problems, personality types, levels of anxiety learn

\section{PENDAHULUAN}

Peradaban manusia bukanlah barang jadi yang jatuh dari langit yang diwarisi secara turun-temurun. Peradaban adalah suatu perjuangan manusia dari abad ke abad dengan menggunakan segala kemampuannya, baik dari lahir maupun yang diperoleh dari pengalaman sebagai hasil budi daya dan rekayasa dalam menghadapi segala hambatan dan tantangan serta keterbatasan-keterbatasan yang dijumpai sepanjang perjalanan hidupnya. Dalam proses itu, pendidikan senantiasa merupakan faktor yang menentukan baik dalam arti peranan, maupun dalam kegunaannya. oleh karena itu dapatlah dipahami kalau immanuel kant (dalam Sahabuddin 2007), seorang filosof jerman yang termahsyur mengatakan bahwa manusia hanya dapat menjadi manusia karena dan oleh pendidikan.

Sistem pendidikan nasional menyatakan bahwa tujuan pendidikan adalah untuk pengembangan potensi siswa untuk menjadi religius dan bertaqwa kepada Tuhan, berakhlak mulia, sehat, berilmu, cakap, kreatif, mandiri,dan menjadi warga negara yang demokratis dan bertanggung jawab (Upu, 2015). Pelajaran matematika adalah salah satu pelajaran yang diajarkan mulai dari sekolah dasar, 
sekolah menengah, sampai perguruan tinggi. Hal itu tidak berlebihan, sebab dengan menguasai dan memahami matematika maka diharapkan bangsa indonesia dapat menguasai dan ikut mengembangkan teknologi. pemecahan masalah merupakan bagian yang penting dalam pembelajaran matematika, karena dengan pemecahan masalah siswa dimungkinkan memperoleh pengalaman menggunakan pengetahuan serta keterampilan yang sudah dimiliki untuk diterapkan pada pemecahan masalah yang bersifat tidak rutin.

Untuk membimbing siswa agar mampu dalam memecahkan masalah matematika khususnya trigometri, seorang guru harus mampu merancang model pembelajaran. Sebuah model pembelajaran dapat sesuai dengan seorang peserta didik, namun bisa jadi tidak sesuai untuk peserta didik lain. Hal ini disebabkan oleh kenyataan bahwa setiap peserta didik adalah individu yang unik dan mempunyai karakteristik yang berbeda-beda. Beberapa hal yang dapat mempengaruhi karakteristik siswa yaitu tipe kepribadian dan tingkat kecemasan belajar yang dimiliki.

Pada tahun 1984, dalam bukunya Please Understand Me I dan II, David Keirsey, seorang profesor dalam bidang psikologi dari California State University, menggolongkan kepribadian menjadi 4 tipe, yaitu Rational, Idealist, Artisan dan Guardian. Individu dengan tipe guardian lebih suka mengikuti prosedur rutin dengan instruksi detail, atau dengan kata lain tipe ini menyukai kelas dengan model tradisional dengan prosedur teratur. Individu dengan tipe artisan menyukai bentuk kelas yang banyak diskusi dan presentasi karena cenderung ingin menunjukan kemampuannya, serta menyukai perubahan dan tidak suka terhadap kestabilan. Individu dengan tipe idealist lebih menyukai meenyelesaikan tugas secara diskusi kelompok, menyukai membaca dan menulis sehingga lebih cocok jika diberi tes berbentuk uraian atau soal cerita. Individu dengan tipe rational menyukai cara belajar dengan pemecahan masalah yang kompleks, lebih suka belajar secara mandiri, serta mampu menangkap abstraksi dan materi yang memerlukan intelektualitas yang tinggi (Keirsey dan Bates, 1984).

Keirsey juga menggolongkan cara berkomunikasi baik lisan maupun tertulis menjadi dua kategori, yaitu konkret dan abstrak. Guardians dan Artisan merupakan komunikator kongkret, sedangkan rational dan idealist adalah komunikator abstrak. Komunikator kongkret lebih menyukai berbicara dan menulis tentang realita, sedangkan komunikator abstrak lebih menyukai berbicara dan menulis tentang ide-ide. Komunikator kongkret menyukai fakta, angka, bukti, sedangkan komunikator abstrak menyukai teori dan hipotesis. Komunikator kongkret berbicara dan menulis secara detail, spesifik, empiris dan faktual. Sedangkan komunikator abstrak secara skematik, umum, teoritis dan fiksi (eko siswono).

Menurut Keirsey cara memilih jalan untuk menyelesaikan masalah digolongkan menjadi dua, yaitu cooperative dan utilitarian. Guardian dan idealist termasuk dalam kategori cooperative, dimana mereka akan memilih cara yang umum digunakan dan diterima kebanyakan orang. Sedangkan artisan dan rational termasuk dalam kategori utilitarian, dimana mereka akan mencari cara yang paling efektif menurut mereka tanpa memikirkan apakah cara tersebut dapat diterima orang lain atau tidak. 
Kecemasan atau anxiety merupakan salah satu bentuk emosi yang berkenaan dengan adanya perasaan terancam oleh sesuatu, biasanya dengan objek ancaman yang tidak jelas. Kecemasan dengan intensitas wajar dapat dianggap memiliki nilai positif sebagai motivasi, namun apabila intensitasnya tinggi dan bersifat negatif dapat menimbulkan kerugian dan dapat mengganggu keadaan fisik dan psikis individu yang bersangkutan (Durand \& Barlow dalam hartati, 1997).

Selanjutnya Ashcraft \& Krause, 2007 (dalam gerard, Ellizabet, susan, 2012) mengatakan "Math anxiety is worrisome because it negatively impacts mathematical knowledge, math grades, and standardized test scores in young adults". Sejalan dengan ashchraft dan krause, Burns dan Zaslavsky mengatakan bahwa " math anxiety is likely to impact the achievement of many students given that survey results show that the majority of individuals in the United States, regardless of cultural and economic background, dislike and fear mathematics". kecemasan matematika ini akan berdampak pada pencapaian siswa baik itu pengetahuan, prestasi dan minat siswa terhadap mata pelajaran matematika.

Menurut Stuart (2006) bahwa kecemasan dapat diekspresikan secara langsung melalui perubahan fisiologis dan perilaku.

a. Gejala kecemasan fisiologis, diantaranya adalah kardiovaskular (jantung berdebar dan rasa ingin pingsan), pernafasan (sesak nafas, tekanan pada dada, dan sensasi tercekik), neuromuskular (insomnia, mondar-mandir, dan wajah tegang), gastrointestinal (nafsu makan hilang, mual, dan diare), saluran perkemihan (tidak dapat menahan kencing), dan kulit (berkeringat, wajah memerah, dan rasa panas dingin pada kulit).

b. Gejala kecemasan perilaku yang meliputi kognitif dan afektif. Perilaku kognitif diantaranya adalah perhatian terganggu, konsentrasi buruk, pelupa, salah memberikan penilaian, hambatan berfikir, kehilangan objektivitas, bingung, takut, dan mimpi buruk. Perilaku afektif diantaranya adalah mudah terganggu, tidak sabar, gelisah, tegang, gugup, ngeri, khawatir, rasa bersalah, dan malu.

Stuart (2006) menjelaskan ada empat tingkat kecemasan, yaitu kecemasan ringan, kecemasan sedang, kecemasan berat, dan panik.

a. Kecemasan ringan

Kecemasan ringan berhubungan dengan ketegangan dalam kehidupan seharihari, kecemasan ini menyebabkan individu menjadi waspada dan meningkatkan lapang persepsinya. Kecemasan ringan dapat memotivasi belajar dan menghasilkan pertumbuhan serta kreativitas. Manifestasi yang muncul pada tingkat ini adalah kelelahan, iritabel, lapang persepsi meningkat, kesadaran tinggi, mampu untuk belajar, motivasi meningkat dan tingkah laku sesuai situasi.

b. Kecemasan sedang

Kecemasan sedang memungkinkan individu untuk berfokus pada hal yang penting dan mengesampingkan yang lain. Kecemasan ini mempersempit lapang persepsi individu, sehingga seseorang mengalami perhatian yang selektif, namun dapat melakukan sesuatu yang terarah. Manifestasi yang terjadi pada tingkat ini yaitu kelelahan meningkat, kecepatan denyut jantung dan 
pernafasan meningkat, ketegangan otot meningkat, bicara cepat dengan volume tinggi, lahan persepsi menyempit, mampu untuk belajar namun tidak optimal, kemampuan konsentrasi menurun, perhatian selektif dan terfokus pada rangsangan yang tidak menambah kecemasan, mudah tersinggung, tidak sabar, mudah lupa, marah dan menangis.

c. Kecemasan berat

Kecemasan berat sangat mengurangi lapang persepsi individu. Individu dengan kecemasan berat cenderung untuk memusatkan pada sesuatu yang terinci dan spesifik, serta tidak dapat berpikir tentang hal lain. Semua perilaku ditujukan untuk mengurangi ketegangan. Manifestasi yang muncul pada tingkat ini adalah mengeluh pusing, sakit kepala, nausea, tidak dapat tidur (insomnia), sering kencing, diare, palpitasi, lahan persepsi menyempit, tidak mau belajar secara efektif, berfokus pada dirinya sendiri dan keinginan untuk menghilangkan kecemasan tinggi, perasaan tidak berdaya, bingung, disorientasi.

d. Panik

Panik berhubungan dengan terperangah, ketakutan dan teror karena mengalami kehilangan kendali. Individu yang mengalami panik tidak mampu melakukan sesuatu walaupun dengan arahan. Panik mencakup disorganisasi kepribadian dan menimbulkan peningkatan aktivitas motoriknya, menurunnya kemampuan untuk berhubungan dengan orang lain, persepsi yang menyimpang, dan kehilangan pemikiran yang rasional. Tingkat kecemasan ini tidak sejalan dengan kehidupan, jika berlangsung terus dalam waktu yang lama, dapat terjadi kelelahan dan kematian.

\section{METODE PENELITIAN}

\section{Jenis penelitian}

Jenis penelitian ini adalah eksploratif dengan pendekatan kualitatif. Penelitian ini berusaha mengungkap secara mendalam kemampuan siswa SMA dalam memecahkan masalah berdasarkan tingkat kecemasan belajar dan penggolongan tipe kepribadian menurut keirsey, yaitu tipe guardian, artisan, rational, dan idealist, dimana dalam memecahkan masalah mengacuh pada langkah-langkah pemecahan masalah menurut polya.

\section{Lokasi penelitian}

Penelitian ini dilaksanakan di SMA Negeri 6 Makassar

\section{Subjek penelitian}

Subjek dalam penelitian ini adalah peserta didik kelas X SMA Negeri 6 Makassar yang di pilih sebanyak 4 siswa berdasarkan tipe kepribadian dan tingkat kecemasan belajar yaitu tipe rational dengan tingkat kecemasan rendah, tipe rational dengan tingkat kecemasan tinggi, tipe idealist dengan tingkat kecemasan rendah, dan tipe idealist dengan tingkat kecemasan tinggi.

\section{Instrumen penelitian}

Karena penelitian ini adalah penelitian kualitatif, maka peneliti adalah instrumen utama dalam pengumpulan data, yang dibantu dengan instrumen pendukung yaitu: instrumen penggolongan tipe kepribadian, instrumen tingkat 
kecemasan belajar matematika siswa, instrumen lembar tugas pemecahan masalah, dan pedoman wawancara.

\section{Teknik analisis data}

Proses analisis data menggunakan model miles dan huberman (dalam sugiyono, 2012: 337-345) yang dilakukan dengan langkah sebagai berikut:

a. Menelaah seluruh data yang tersedia dari berbagai sumber, yaitu dari wawancara, pengamatan yang sudah dituliskan, dalam catatan lapangan, dan hasil tes soal matematika.

b. Data reduction (reduksi data)

c. Data display (penyajian data)

d. Membuat Coding.

e. Conclusion drawing (penarikan kesimpulan).

\section{HASIL PENELITIAN DAN PEMBAHASAN}

Berikut adalah temuan hasil penelitian kemampuan pemecahan masalah matematika siswa berdasarkan tipe kepribadian dan kecemasan belajar matematika dari 30 siswa kelas X SMA Negeri 6 Makassar, dipilih 4 siswa sebagai subjek penelitian. Pemilihan ini berdasarkan pertimbangan/pendapat guru atau pihak lain dengan memperhatikan kriteria: (1) tipe kepribadian, (2) tingkat kecemasan belajar matematika, (3) keaktifan selama pembelajaran matematika, dan (4) dapat mengemukakan pendapat/jalan pikirannya secara lisan maupun tulisan.

Tabel 1 : subjek penelitian

\begin{tabular}{lll} 
Kepribadian & Kecemasan tinggi & \\
\hline Idealist & Nur Alya azzahra & Fecemasan rendah \\
\hline Rational & Nurhaliza. $\mathrm{M}$ & Nuraulia
\end{tabular}

siswa yang terpilih sebagai subjek penelitian pada tipe kepribadian idealist dengan tingkat kecemasan tinggi dan rendah masing-masing diberi inisial IT dan $I R$ sedangkan siswa yang terpilih sebagai subjek penelitian pada tipe kepribadian rational dengan tingkat kecemasan tinggi dan rendah diberi inisial $R T$ dan $R R$.

Berikut adalah temuan hasil penelitian kemampuan pemecahan masalah matematika siswa berdasarkan tipe kepribadian dan kecemasan belajar matematika

Kemampuan pemecahan masalah matematika siswa tipe idealist dengan tingkat kecemasan tinggi.

\begin{tabular}{|c|c|c|}
\hline No & $\begin{array}{c}\text { Pemecahan } \\
\text { masalah }\end{array}$ & Karakter idealist \\
\hline
\end{tabular}




\begin{tabular}{llll}
\hline \hline Memahami & $\begin{array}{l}\text { melakukan proses } \\
\text { masalah }\end{array}$ & $\begin{array}{l}\text { perhatian menjadi terganggu , } \\
\text { konsentrasi buruk, tidak sabar } \\
\text { dalam menyelesaikan tugas }\end{array}$ \\
\hline 2 & $\begin{array}{l}\text { Membuat } \\
\text { rencana } \\
\text { pemecahan } \\
\text { masalah }\end{array}$ & $\begin{array}{l}\text { melakukan proses } \\
\text { berfikir abstraksi }\end{array}$ & $\begin{array}{l}\text { bingung dalam menentukan } \\
\text { informasi yang tepat digunakan } \\
\text { dalam menyelesaikan soal }\end{array}$ \\
\hline $\begin{array}{l}\text { Melaksanakan } \\
\text { rencana }\end{array}$ & $\begin{array}{l}\text { melakukan proses } \\
\text { berfikir abstraksi serta } \\
\text { menyelesaikan masalah } \\
\text { dengan kategori } \\
\text { cooperative }\end{array}$ & $\begin{array}{l}\text { terburu-buru sehingga tidak } \\
\text { menuliskan langkah-langkah } \\
\text { penyelesaian dengan lengkap, raut } \\
\text { wajah tegang, dan sering salah } \\
\text { menyebutkan istilah-istilah yang } \\
\text { digunakan saat menjawab } \\
\text { pertanyaan peneliti. }\end{array}$ \\
\hline
\end{tabular}

\begin{tabular}{|c|c|c|c|}
\hline No & $\begin{array}{l}\text { Pemecahan } \\
\text { masalah }\end{array}$ & Karakter idealist & Gejala kecemasan \\
\hline 1 & $\begin{array}{l}\text { Memahami } \\
\text { masalah }\end{array}$ & $\begin{array}{l}\text { melakukan proses berfikir } \\
\text { abstraksi }\end{array}$ & $\begin{array}{llr}\text { gugup } & \text { dalam } & \text { dalam } \\
\text { menjawab } & \text { pertanyaan yang } \\
\text { diajukan peneliti } & \end{array}$ \\
\hline 2 & $\begin{array}{l}\text { Membuat } \\
\text { rencana } \\
\text { pemecahan } \\
\text { masalah }\end{array}$ & $\begin{array}{l}\text { melakukan proses berfikir } \\
\text { abstraksi }\end{array}$ & $\begin{array}{l}\text { Gejala kecemasan yang terlihat } \\
\text { saat wawancara yaitu subjek } \\
I R \text { salah menyebutkan rumus } \\
\text { dikarenakan subjek IR } \\
\text { cenderung tegang dan gugup. }\end{array}$ \\
\hline 3 & $\begin{array}{l}\text { Melaksanakan } \\
\text { rencana }\end{array}$ & $\begin{array}{l}\text { melakukan proses berfikir } \\
\text { abstraksi dan } \\
\text { menyelesaikan masalah } \\
\text { dengan kategori } \\
\text { cooperative }\end{array}$ & $\begin{array}{l}\text { konsentrasi yang buruk dan } \\
\text { perhatian terganggu sehingga } \\
\text { melakukan kesalahan algoritma }\end{array}$ \\
\hline
\end{tabular}

Kemampuan pemecahan masalah matematika siswa tipe rational dengan tingkat kecemasan tinggi

\begin{tabular}{llll}
\hline No & $\begin{array}{c}\text { Pemecahan } \\
\text { masalah }\end{array}$ & \multicolumn{1}{c}{ Karakter rational } & \multicolumn{1}{c}{ Gejala kecemasan } \\
\hline 1 & Memahami & melakukan proses berfikir & konsentrasi yang buruk \\
masalah & $\begin{array}{l}\text { abstraksi , selalu } \\
\text { memperhatikan efisiensi dari }\end{array}$ & $\begin{array}{l}\text { terganggu yang } \\
\text { memikirannya }\end{array}$ \\
& & segala hal yang dilakukan & mengakibatkan tidak \\
& sehingga subjek $R T$ tidak & fokus \\
& menuliskan dengan lengkap & \\
& apa yang diketahui dan apa & \\
& yang ditanyakan pada soal & \\
& &
\end{tabular}




\begin{tabular}{|c|c|c|c|}
\hline & & $\begin{array}{l}\text { karena hal itu sudah sangat } \\
\text { jelas }\end{array}$ & \\
\hline 2 & $\begin{array}{l}\text { Membuat } \\
\text { rencana } \\
\text { pemecahan } \\
\text { masalah }\end{array}$ & $\begin{array}{l}\text { melakukan proses berfikir } \\
\text { abstraksi }\end{array}$ & $\begin{array}{l}\text { perhatian terganggu serta } \\
\text { ada perasaan gugup dan } \\
\text { tegang saat wawancara } \\
\text { sehingga setiap memberikan } \\
\text { jawaban, subjek } R T \text { terkesan } \\
\text { ragu dan sedikit kaku }\end{array}$ \\
\hline 3 & $\begin{array}{l}\text { Melaksanakan } \\
\text { rencana }\end{array}$ & $\begin{array}{l}\text { melakukan proses berfikir } \\
\text { abstraksi menyelesaikan } \\
\text { masalah dengan kategori } \\
\text { utilitarian }\end{array}$ & $\begin{array}{l}\text { terburu-buru sehingga tidak } \\
\text { menuliskan langkah- } \\
\text { langkah penyelesaian } \\
\text { dengan lengkap }\end{array}$ \\
\hline
\end{tabular}

Kemampuan pemecahan masalah matematika siswa tipe rational dengan tingkat kecemasan rendah.

\begin{tabular}{|c|c|c|c|}
\hline No & $\begin{array}{l}\text { Pemecahan } \\
\text { masalah }\end{array}$ & Karakter rational & Gejala kecemasan \\
\hline 1 & $\begin{array}{l}\text { Memahami } \\
\text { masalah }\end{array}$ & $\begin{array}{l}\text { melakukan proses berfikir } \\
\text { abstraksi, selalu memperhatikan } \\
\text { efisiensi dari segala hal yang } \\
\text { dilakukan sehingga subjek } R T \\
\text { tidak menuliskan dengan lengkap } \\
\text { apa yang diketahui dan apa yang } \\
\text { ditanyakan pada soal karena hal } \\
\text { itu sudah sangat jelas }\end{array}$ & konsentrasi buruk \\
\hline 2 & $\begin{array}{l}\text { Membuat } \\
\text { rencana } \\
\text { pemecahan } \\
\text { masalah }\end{array}$ & $\begin{array}{l}\text { melakukan proses berfikir } \\
\text { abstraksi }\end{array}$ & gugup atau tegang \\
\hline 3 & $\begin{array}{l}\text { Melaksanakan } \\
\text { rencana }\end{array}$ & $\begin{array}{l}\text { melakukan proses berfikir } \\
\text { abstraksi menyelesaikan masalah } \\
\text { dengan kategori utilitarian }\end{array}$ & $\begin{array}{l}\text { timbul rasa malu dan } \\
\text { tidak yakin untuk } \\
\text { membenarkan jawaban } \\
\text { yang telah diperoleh }\end{array}$ \\
\hline
\end{tabular}

\section{Pembahasan}

1. Subjek idealist dengan tingkat kecemasan tinggi dalam memecahkan masalah yaitu:

a. Memahami masalah: pada tahap memahami masalah IT tidak menuliskan dengan benar dan lengkap apa yang diketahui dan apa yang ditanyakan pada soal. Jadi meskipun pada dasarnya tipe idealist senang dalam menulis namun faktor kecemasan yang tinggi mengakibatkan subjek IT perhatiannya terganggu dan konsentrasi buruk serta tidak sabar ingin melangkah ke tahap selanjutnya untuk menyelesaikan soal. 
b. Merencanakan strategi: dalam tahap merencanakan strategi, subjek IT mampu dalam menentukan informasi yang relevan untuk menyelesaikan soal namun kadang bingung saat wawancara. Hal ini sesuai dengan karakterisktik idealis yang lebih suka menulis daripada menjelaskan pendapat secara lisan. Gejala kecemasan yang muncul saat proses wawancara yaitu subjek IT bingung dalam menentukan informasi yang tepat digunakan dalam menyelesaikan soal.

c. Melaksanakan rencana: subjek IT mampu mengerjakan soal sesuai dengan langkah pemecahan masalah yang telah direncanakan sebelumnya namun tidak mampu menyelesaikan tepat waktu. Karakteristik idealist yang nampak saat penyelesaian soal yaitu tidak menyukai batasan waktu sehingga santai dalam menyelesaikan soal sehingga kehabisan waktu untuk menjawab soal bagian $b$, hal ini dapat juga diakibatkan oleh gejala kecemasan tinggi yang dialami subjek IT sehingga mengalami hambatan dalam berfikir.

2. Subjek idealist dengan tingkat kecemasan rendah dalam memecahkan masalah yaitu:

a. Memahami masalah: pada tahap memahami masalah, $I R$ mampu menuliskan apa yang diketahui dan apa yang ditanyakan pada soal dengan jelas. Dengan melihat hasil kerja siswa pada saat tes tertulis dimana siswa mampu menuliskan apa yang diketahui dan apa yang ditanyakan dengan lengkap dan jelas menunjukkan karateristik idealist yang suka menulis, hal ini didukung oleh tingkat kecemasan rendah yang dialami subjek $I R$ sehingga mampu untuk lebih fokus.

b. Merencanakan strategi: pada tahap ini subjek $I R$ mampu mengaitkan antara hal yang diketahui dan hal yang ditanyakan untuk menentukan rumus yang tepat dalam menjawab pertanyaan. Hal ini sesuai dengan karakteristik idealist yang memproses data dengan melihat pada pola dan hubungan, meskipun saat wawancara salah menyebutkan rumus dikarenakan subjek $I R$ sedikit tegang dan gugup.

c. melaksanakan rencana: pada tahap ini $I R$ menggunakan langkah-langkah yang telah disusun sebelumnya secara benar, meskipun dalam tahap penyelesaian salah dalam perhitungan. Karakteristik idealist yang muncul pada subjek $I R$ yaitu cepat dalam bertindak, namun dampaknya subjek $I R$ kurang hati-hati dalam melakukan perhitungan. Gejala kecemasan yang muncul yaitu konsentrasi yang buruk dan perhatian terganggu sehingga melakukan kesalahan algoritma.

3. Subjek rational dengan tingkat kecemasan tinggi dalam memecahkan masalah yaitu:

a. Memahami masalah: pada tahap ini terkadang subjek $R T$ tidak menuliskan dengan lengkap apa yang diketahui dan apa yang ditanyakan pada soal karena hal itu sudah sangat jelas. Subjek $R T$ menganggap bahwa hal yang sudah jelas bagi mereka aka jelas juga bagi orang lain, sehingga untuk menuliskannya hanya akan membuang-buang waktu dan tenaga. Hal ini sesuai dengan karakter rational yang selalu memperhatikan efisiensi dari segala hal yang dilakukan, faktor lain yang mendukung adalah tingginya 
tingkat kecemasan yang membuat konsentrasi buruk serta pemikirannya terganggu.

b. Merencanakan strategi: pada tahap ini subjek $R T$ mampu menerima informasi yang ada pada soal dan menghubungkan untuk menentukan rumus yang tepat dalam menyelesaikan soal namun pada masalah yang berbeda, subjek $R T$ tidak memahami konsep sehingga salah dalam menentukan rumus. Hal ini disebabkan oleh tingkat kecemasan yang tinggi sehingga subjek $R T$ terkadang ragu dan sedikit kaku dalam menjawab pertanyaan.

c. Melaksanakan rencana: pada tahap ini menunjukkan bahwa subjek $R T$ mampu menyelesaikan soal sesuai strategi yang telah dirancang. Namun terkadang mempunyai cara-cara yang unik dan inovatif dalam menyelesaikan masalah meskipun pemilihan cara tersebut tidak sesuai dengan apa yang diinginkan soal.

4. Subjek rational dengan tingkat kecemasan rendah dalam memahami masalah yaitu:

a. Memahami masalah: subjek $R R$ kurang lengkap dalam menuliskan apa yang diketahui pada soal namun dapat menuliskan dengan jelas apa yang ditanyakan karena tipe ini cenderung mengabaikan hal-hal yang dirasa tidak perlu atau membuang waktu. Karena hal yang diketahui pada soal dirasa sudah jelas, maka subjek $R R$ tidak menuliskannya dengan beranggapan bahwa hal yang sudah jelas bagi mereka, sudah jelas juga bagi orang lain sehingga untuk menuliskannya hanya akan membuang waktu dan tenaga. Karakteristik rational yang muncul pada subjek $R R$ saat memahami masalah yaitu selalu berusaha untuk mengurangi atau membatasi penjelasannya sehingga untuk menjelaskan ide/isi fikirannya mereka memilih menggunakan gambar. Subjek $R R$ tidak menunjukkan gejala kecemasan pada tahap memahami masalah.

b. Merencanakan strategi: pada tahap ini subjek $R R$ mampu mengaitkan informasi yang ada pada soal untuk menentukan langkah penyelesaian. Karakteristik rational yang terlihat pada tahap perencanaan pemecahan masalah yaitu memproses data dengan melihat pada pola dan hubungan serta bagus dalam menganalisa

c. Melaksanakan rencana: pada tahap ini subjek $R R$ menggunakan langkahlangkah secara benar, serta terampil dalam algoritma dan ketepatan menjawab soal. Karakteristik rational yang muncul pada subjek $R R$ pada tahap menyelesaikan masalah yaitu "menerapkan prinsip dan konsisten". Adapun gejala kecemasan yang dialami subjek $R R$ pada tahap melaksanakan rencana yaitu timbul rasa malu dan tidak yakin untuk membenarkan jawaban yang telah diperoleh.

\section{SIMPULAN DAN SARAN Simpulan}

Berdasarkan hasil analisis data dan pembahasan yang telah dikemukakan pada bab sebelumnya, maka ditarik kesimpulan penelitian sebagai berikut: 
1. Kemampuan pemecahan masalah trigonometri subjek idealist dengan tingkat kecemasan tinggi dalam memecahkan masalah yaitu: (a) Memahami masalah: pada tahap memahami masalah subjek IT tidak menuliskan dengan benar dan lengkap apa yang diketahui dan apa yang ditanyakan. (b) Merencanakan strategi: subjek IT mampu dalam menentukan informasi yang relevan untuk menyelesaikan soal. (c) Melaksanakan rencana: subjek IT mampu mengerjakan soal sesuai dengan langkah pemecahan masalah yang telah direncanakan sebelumnya.

2. Kemampuan pemecahan masalah trigonometri subjek idealist dengan tingkat kecemasan rendah dalam memecahkan masalah yaitu: (a) Memahami masalah: pada tahap ini, IR mampu menuliskan apa yang diketahui dan apa yang ditanyakan. (b) Merencanakan strategi: pada tahap ini subjek $I R$ mampu mengaitkan antara hal yang diketahui dan hal yang ditanyakan untuk menentukan rumus yang tepat. (c) melaksanakan rencana: pada tahap ini $I R$ menggunakan langkah-langkah yang telah disusun sebelumnya secara benar.

3. Kemampuan pemecahan masalah trigonometri subjek rational dengan tingkat kecemasan tinggi dalam memecahkan masalah yaitu: (a) Memahami masalah: pada tahap ini subjek $R T$ tidak menuliskan dengan lengkap apa yang diketahui dan apa yang ditanyakan pada soal karena hal itu sudah sangat jelas. (b) Merencanakan strategi: pada tahap ini subjek $R T$ mampu menerima informasi yang ada pada soal dan menghubungkan untuk menentukan rumus yang tepat dalam menyelesaikan soal namun pada masalah yang berbeda, subjek $R T$ tidak memahami konsep sehingga salah dalam menentukan rumus. (c) Melaksanakan rencana: pada tahap ini menunjukkan bahwa subjek $R T$ mampu menyelesaikan soal sesuai strategi yang telah dirancang.

4. Kemampuan pemecahan masalah trigonometri subjek rational dengan tingkat kecemasan rendah dalam memahami masalah yaitu: (a) Memahami masalah: subjek $R R$ kurang lengkap dalam menuliskan apa yang diketahui pada soal karena tipe ini cenderung mengabaikan hal-hal yang dirasa tidak perlu atau membuang waktu. (b) Merencanakan strategi: pada tahap ini subjek $R R$ mampu mengaitkan informasi yang ada pada soal. (c) Melaksanakan rencana: pada tahap ini subjek $R R$ menggunakan langkah-langkah secara benar, serta terampil dalam algoritma dan ketepatan menjawab soal.

\section{Saran}

Berdasarkan kesimpulan pada penelitian ini, dalam pembelajaran pemecahan masalah matematika berdasarkan langkah-langkah Polya disarankan kepada guru matematika sebagai berikut.

1. Perlu diadakan penelitian lebih lanjut tentang jumlah atau persentase masingmasing tipe kepribadian siswa dan tingkat kecemasan belajarnya untuk dapat dijadikan pedoman dalam penyusunan kurikulum, mengingat tipe belajar dari masing-masing tipe kepribadian tidak sama serta dalam pengumpulan data saat wawancara menggunakan media berupa alat perekam dan juga catatan kecil (manuskrip) untuk menjaga kevalidan data yang diperoleh.

2. Guru diharapkan mampu membuat suatu model pembelajaran yang disenangi oleh siswa sehingga mereka tertarik dengan pelajaran matematika, karena salah 
satu faktor yang mampu menekan tingkat kecemasan belajar yaitu dengan menyukai apa yang dipelajari.

3. Pada langkah memahami masalah, terhadap siswa dengan tipe rational, baik itu kecemasan tinggi maupun rendah sebaiknya guru membimbing atau membiasakan siswa untuk menuliskan hal-hal yang diketahui (syarat cukup) dan hal-hal yang ditanyakan (syarat perlu), demikian juga terhadap siswa tipe idealist, meskipun siswa tipe idealist sudah dapat menuliskan apa yang diketahui dan ditanyakan secara implisit.

\section{DAFTAR PUSTAKA}

Hartanti \& Judith E.D. (1997). Hubungan Antara Konsep Diri dan Kecemasan Menghadapi Masa Depan dengan Penyesuaian Sosial Anak-anak Madura. Jurnal Psikologi Pendidikan: Anima. 12, 46, 2007.

Keirsey, David. 1984. Please understand me I (temperament sorter model). Promotheus Nemesis Book Company: California.

Keirsey, David. 1988. Please understand me II (temperament character and intelligence). Printed in the United States of America: USA.

Krulik, J \& Rudnik, J. A. 1988. Problem Solving a Handbook for Elementary School Teachers. Temple University. USA.

Munasiah. 2015. Pengaruh Kecemasan Belajar Dan Pemahaman Konsep Matematika Siswa Terhadap Kemampuan Penalaran Matematika.

Jurnal Formatif 5(3): 220- 232, 2015 ISSN: 2088-351X.

Polya, George. 1945. How to Solve it, Second Edition. Princeton: Princeton University Press.

Ramirez, Gerard, dkk. 2012. Math Anxiety, Working Memory, And Math Achievement In Early Elementary School. The University of Chicago.

Upu, Hamzah. 2015. Analysis understanding of the SMP student build concept and principle of flatin math. Post graduate program, Makassar state university.

Yuwono, Aries. 2010. Profil siswa sma dalam memecahkan Masalah matematika ditinjau Dari tipe kepribadian. Program studi pendidikan matematika Program pascasarjana Universitas sebelas maret: Surakarta 